Jurnal Keperawatan Padjadjaran

ISSN 2338-5324 (print)

ISSN 2442-7276 (online)

Online di http://jkp.fkep.unpad.ac.id

DOI : $10.24198 / \mathrm{jkp}$

\title{
Research Priority of Gerontic Nursing in Indonesia: findings from a Delphi Study
}

\author{
I Gede Putu Darma Suyasa*, Ni Kadek Sutini \\ Institut Teknologi dan Kesehatan Bali, Denpasar, Indonesia \\ CorrespondingEmail: putudarma.stikesbali@gmail.com
}

Received: 23-11-2020 Revised: 15-02-2021 Accepted: 17-02-2021

\begin{abstract}
While elderly population in Indonesia continues to increase, research around elderly and health care for elderly is still limited. The purpose of this study was to identify priority of research area on Gerontic Nursing in Indonesia. This was a descriptive study, using Delphi study with 2 survey rounds. Round 1 involved 34 participants purposely selected among nurses who worked in the area of and had a research interest in Gerontic Nursing. Open ended online questionnaire about priority areas was sent to potential participants. Data was analyzed for its similarity, resulted in 36 research areas around Gerontic Nursing. Round 2 involved 204 nurses with the same criteria as in round 1, selected using convenience sampling technique. Close ended questionnaire using Semantic Differential Scale ranged from 1 to 9 was sent online to potential participants. Data was descriptively analyzed for median, interquartile range (IQR), and range. Findings indicated 10 levels of research priority. Level 1 research priority with median of 9, IQR 1, and range 5 were long term care for elderly, family knowledge on caring for elderly, personal hygiene in elderly, competency of Gerontic Nurse, and nutrition in elderly. Nurse academics and researchers are suggested to collaborate with nurse practitioners in various settings to conduct research on these priority areas.
\end{abstract}

Keywords: Delphi study, elderly, gerontic nursing, long-term care. 
I Gede Putu Darma Suyasa: Research Priority of Gerontic Nursing in Indonesia: Findings from a Delphi Study

\section{Introduction}

Elderly population in Indonesia has doubled in the last five decades. By 2019, this specific group of population had reached 25,6 million or $9,6 \%$ of Indonesia total population (Biro Pusat Statistik, 2019). With a significant increase of elderly population, nursing as an integral part of national healthcare system should provide high quality health services in order to maintain adequate quality of life among elderly. This becomes more important especially in a specific circumstance such as Covid-19 pandemic, where Indonesia is reported as a country with high death rate among elderly population (United Nations, 2020).

In order to provide a better care for elderly, evidence-based practice resulted from rigorous studies is essential to provide safe and efficient outcomes for patients (Grove \& Gray, 2018). Rigorous studies are achieved when researchers follow appropriate guidelines, procedures and design in conducting their research. In addition, it is also essential that researchers provide adequate reasons with clear explanation of why particular studies are important. Evidence from research priority may help researcher to do this.

Some studies involving elderly and healthcare for elderly in Indonesia are already conducted. These studies include research on anxiety to death, that indicates satisfaction in life as the dominant factors associated with death anxiety among specific ethnic group in Indonesia (Lukman et al., 2018). A study in nursing homes on dementia is also conducted in West Java. Findings indicate that low education, cerebrovascular diseases, and diabetes mellitus are predictors of dementia among elderly (Fitriana et al., 2020). A research on family support intervention for elderly with chronic condition has been conducted in Jakarta, resulted in evidence to support policy for family empowerment in caring for older people (Maryam et al., 2018).

The studies above are examples of some studies conducted in Indonesia among elderly that has notably given substantial empirical evidence for the development of nursing knowledge and nursing practices. However, there are no studies identifying which research areas are considered as priority in
Gerontic Nursing. By identifying priorities, nurse practitioners, nurse academics, and nurse researchers may refocus their research area for the development of the most needed evidence in caring for the elderly. In addition, research priorities identified by nurses working in the specific area are more relevant to the specialty and minimize the gap between theory and practice (Ramelet et al., 2012). This current study is the very first research aimed at identifying priority of research area on Gerontic Nursing in Indonesia.

There are several methods to priorities research area; including Delphi study, nominal group technique, and consensus development conference. Nominal group technique and consensus development conference require physical meeting to gain group consensus, which would have been difficult to achieve in the current study because of two reasons. First, participants for this study are nurses from all around Indonesia. Secondly, in order to obey health protocols, physical meeting is prohibited due to Covid-19 pandemic. Delphi studies are able to bridge this issue because they allow national participants over a wide geographic area to express their opinions without having to conduct a physical meeting (Keeney et al., 2017).

The term Gerontic Nursing is used and has been agreed by nursing experts in Indonesia. This is because Gerontic Nursing reflects nursing for elderly with its three essential elements of nursing i.e. nurturing, caring and comforting (Meiner \& Yeager, 2019). Other countries such as Australia and the US prefer the term Gerontologic Nursing. The term Gerontic Nursing is also used in nursing curriculum in Indonesia.

\section{Method}

This was a descriptive research using Delphi Study. The Delphi technique was developed by Dalkey and associates at the Research and Development (RAND) Corporation. This technique has three distinctive characteristics. First, it has anonymous response where opinions of members of the group are obtained by formal questionnaire. Second, there is an iteration and controlled feedback where interaction among participants is affected by 
a systematic exercise conducted in several iterations, with carefully controlled feedback between rounds. Third, it has statistical group responses where group opinion is defined as an appropriate aggregate of individual opinions in the final rounds (Diamond et al., 2014).

Delphi study consists of 2-3 surveys involving participants or experts in the related fields. Delphi study as a research design has been utilized in nursing in a wide range of studies such as identifying nurse competencies (Collins et al., 2017), developing a self-care guideline (Suyasa, 2013), identifying priorities for nurse's professional development (Cooper et al., 2017), and analyzing nursing research priorities in critical care (Acosta et al., 2020).

Delphi study in this research was designed as a 2-round survey. Participants in all rounds were considered as experts in this study. They were nurses who were already providing care for elderly in hospitals, community, nursing homes; lecturers in nursing institutions, and researchers who had interest in Gerontic Nursing all around Indonesia.

\section{Delphi Study Round 1}

Round 1 Delphi Study involved 34 participants purposely selected among nurses who were currently providing care for elderly in hospitals, community, nursing homes, lecturers in nursing institutions and researchers who had interest in Gerontic Nursing all around Indonesia with minimum educational background of DIII in nursing. Open ended online questionnaire about research area or specific topic in Gerontic Nursing was sent to potential participants. Information sheet was also sent to potential participants, and they were requested to participate in the study using online system via email and WhatsApp application. They were asked to consent prior to data collection. Data collection for round 1 was conducted in November 2020. As data in round 1 was collected using open ended questionnaire, the data analysis was done following three steps: 1) reading the whole data to see various responses from participants, 2) collapsing the same or similar statements into one statement, and 3) keeping the wording as true as possible to one of the statements provided by the experts (Keeney et al., 2017). This resulted in 36 research areas around Gerontic Nursing. In order to validate the findings in round 1, all 36 research areas were sent back to participants. All agreed that the areas were relevant as item measures for round 2 Delphi Study.

\section{Delphi Study Round 2}

Round 2 involved 204 nurses with the same criteria as in round 1. Participants in round 2 were selected using convenience sampling technique. Questionnaire in round 2 was developed based on responses in round 1. Close ended questionnaire using Semantic Differential Scale ranged from 1 to 9 was sent online to potential participants. The lowest priority represents as 1 and the highest priority represents as 9. Information sheet was sent to potential participants and they were requested to participate in the study using online system via email and WhatsApp application. They were asked to consent prior to data collection. Data collection for round 2 was conducted in November 2020. Prior to data analyses, data was checked for error and missing. In this study, no data error and missing were found. After data checking, descriptive analyses were conducted for median, interquartile range (IQR), and range using SPSS version 20. The IQR is calculated as the difference between the third and the first quartile. The conclusion for research priority was made following rules that the higher the median, the smaller the IQR and range, means the higher the research priority.

This study was approved by Research Ethics Committee of Institute of Technology and Health Bali, reference number 03.006.2/ KEPITEKES-BALI/IV/2020.

Table 1 Summary of Research Method in Round 1 and Round 2

\begin{tabular}{lll}
\hline \multicolumn{1}{c}{ Method } & \multicolumn{1}{c}{ Round 1 } & \multicolumn{1}{c}{ Round 2 } \\
\hline Sampling technique & Purposive & Convenience \\
Sample size & 34 & 204 \\
Questionnaire & Open ended & Close ended (Semantic Differential Scale) \\
Data analyses & Qualitative & Quantitative (Median, IQR, Range) \\
\hline
\end{tabular}


I Gede Putu Darma Suyasa: Research Priority of Gerontic Nursing in Indonesia: Findings from a Delphi Study

\section{Results}

Demographic characteristic of participants The majority of participants in round 1 and 2 were females (55.9 and 69.1, respectively), and mostly working as academic/researcher (58.8 and 42.6, respectively). In terms of educational background, $50 \%$ of participants in round 1 had master level, and $32.4 \%$ of participants in round 2 were graduated from Ners Profession (Details are presented in Table 2). Especially in round 2, participants were a representation from 14 provinces in Indonesia, including Bali, East Nusa, West Nusa, South Sulawesi, South East Sulawesi, Maluku, Banten, Jakarta, East Java, Central Java, West Java, Riau, Papua, and West Papua.

Table 2 Gender and Educational Background of Participants in Round 1 and Round 2

\begin{tabular}{lcccc}
\hline \multirow{2}{*}{ Characteristic } & \multicolumn{2}{c}{ Round 1 (N=34) } & \multicolumn{2}{c}{ Round 2 (N=204) } \\
\cline { 2 - 5 } & $\mathbf{n}$ & $\mathbf{\%}$ & $\mathbf{n}$ & $\mathbf{\%}$ \\
\hline Gender & & & 63 & 30.9 \\
Male & 15 & 44.1 & 141 & 69.1 \\
Female & 19 & 55.9 & & \\
Education & & & 27 & 13.2 \\
Diploma III & 5 & 14.7 & 29 & 14.2 \\
Bachelor/Bachelor & 4 & 11.8 & & 32.4 \\
of Applied Science & & & 66 & 28.4 \\
Ners Profession & 1 & 2.9 & 58 & 5.9 \\
Master & 17 & 50.0 & 12 & 5.9 \\
Nursing Specialist & 6 & 17.7 & 12 & \\
Doctor & 1 & 2.9 & & \\
\hline
\end{tabular}

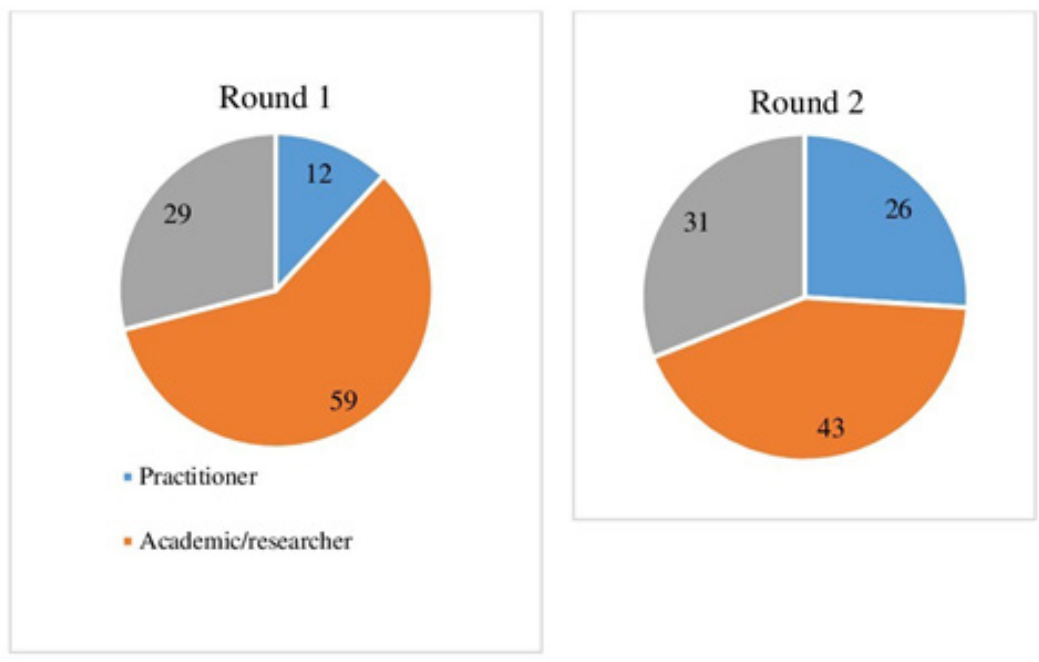

Figure 1 Roles of Participants in Round 1 and Round 2 
I Gede Putu Darma Suyasa: Research Priority of Gerontic Nursing in Indonesia: Findings from a Delphi Study

Roles of participants in nursing are an important figure for the study as it reflects the expertise of participants. As illustrated in Figure 1 below, most participants $(59 \%$ and $43 \%$, respectively) in Round 1 and 2 had roles as academics/researcher.

\section{Findings of round 1}

Responses from open ended questionnaire in round 1 were analyzed for its similarity resulted in the identification of 36 research areas in Gerontic Nursing (Table 3, column 1). These areas are the source for quantitative, close ended questionnaire in round 2.

\section{Findings of round 2}

Based on statistical analyses of median,
IQR and range, there were 10 levels of research priority. Level 1 research priority with median of 9, IQR 1, and range 5 were long term care for elderly, family knowledge on caring for elderly, personal hygiene in elderly, standard competency of Gerontic Nurse, and nutrition in elderly. Level 2 research priority with median of $9, \mathrm{IQR}=1$, and range 7 were psychological problems and daily living activities in elderly. Meanwhile level 3 research priority with median of 9 , $\mathrm{IQR}=1$, and range 8 were psychological problems in elderly and daily living activities. In addition, neglect and aloneness among elderly in Indonesia (median of 8, IQR=2, and range 8) was considered as the lowest level of priority. Details are presented in Table 3.

Table 3 Priority Level of Research Area in Gerontic Nursing ( $N=204)$

\begin{tabular}{lccc}
\hline \multicolumn{1}{c}{ Research area identified in Round 1 } & Median & IQR & Range (min-max) \\
\hline Level 1 & 9 & 1 & $5(4-9)$ \\
Long term care for elderly & 9 & 1 & $5(4-9)$ \\
Family knowledge on caring for elderly & 9 & 1 & $5(4-9)$ \\
Personal hygiene in elderly & 9 & 1 & $5(4-9)$ \\
Standard competency of Gerontic Nurse & 9 & 1 & $5(4-9)$ \\
Nutrition in elderly & & & \\
Level 2 & 9 & 1 & $7(4-9)$ \\
Psychological problems in elderly & 9 & 1 & $7(4-9)$ \\
Daily living activities of elderly & & & \\
Level 3 & 9 & 1 & $8(1-9)$ \\
Quality of life of elderly & 9 & 1 & $8(1-9)$ \\
Fall prevention in elderly & 9 & 1 & $8(1-9)$ \\
Immune system in elderly & & & \\
Level 4 & 9 & 2 & $5(4-9)$ \\
Comorbid condition in elderly & & & \\
Level 5 & 8 & 1 & $6(3-9)$ \\
Nursing intervention in elderly & & & \\
Level 6 & 8 & 1 & $7(2-9)$ \\
Family role in caring for elderly & 8 & 1 & $7(2-9)$ \\
Non-communicable diseases in elderly & 8 & & \\
Level 7 & 8 & 2 & $5(4-9)$ \\
Preventive health care for elderly & 8 & $5(4-9)$ \\
Degenerative diseases in elderly & & $5(4-9)$ \\
Culture of caring for elderly & 8 & $5(4-9)$ \\
Musculoskeletal problems in elderly & & & \\
Readiness for quality Aged Care Facilities & 8 & & \\
\hline & & 2 & \\
\hline
\end{tabular}


I Gede Putu Darma Suyasa: Research Priority of Gerontic Nursing in Indonesia: Findings from a Delphi Study

\begin{tabular}{lccc}
\hline \multicolumn{1}{c}{ Research area identified in Round 1 } & Median & IQR & Range (min-max) \\
\hline Level 8 & & & \\
Technology support in caring for elderly & 8 & 2 & $6(3-9)$ \\
Medication management in elderly & 8 & 2 & $6(3-9)$ \\
Roles of nurses in caring for elderly at home & 8 & 2 & $6(3-9)$ \\
Health promotion in elderly & 8 & 2 & $6(3-9)$ \\
Development of tools/equipment for & 8 & 2 & $6(3-9)$ \\
fulfilment in daily needs of elderly & & 2 & $6(3-9)$ \\
Socio-cultural aspects of elderly & 8 & & \\
Level 9 & & 2 & $7(2-9)$ \\
Spiritual aspects of elderly & 8 & 2 & $7(2-9)$ \\
Assessment tools for elderly & 8 & 2 & $7(2-9)$ \\
Fear of loss in elderly & 8 & 2 & $7(2-9)$ \\
Anxiety in elderly & 8 & 2 & $7(2-9)$ \\
Family relation in caring for elderly & 8 & 2 & $7(2-9)$ \\
Incontinence in elderly & 8 & 2 & $7(2-9)$ \\
Activities during hospitalization & 8 & & \\
Level 10 & & 2 & $8(1-9)$ \\
Neglect in elderly & 8 & 2 & $8(1-9)$ \\
Aloneness in elderly & 8 &
\end{tabular}

Besides research priority as presented in Table 4, participants in round 2 also suggested other research areas including behavioral risk factors in elderly, elderly in disaster condition, end of life care, terminal care, hospice care, adverse life events, health literacy, recreational needs in elderly, occupational and modality therapy, caring for elderly in Covid-19, caregiver burden, intergenerational relationship, self-efficacy, and family resilience.

\section{Discussion}

This is the very first study in Indonesia to identify research priority in Gerontic Nursing. Literature search using EBSCOHOST, ProQuest, and Science and Technology Index (SINTA) could not identify similar study in the Indonesian setting. Nurses, not only in Indonesia, but also worldwide, constitute the largest health workforce and play essential roles in health care for the elderly. Therefore, nurse's involvement in research is important to support evidence-based practice in Indonesia.
Indonesia is one of the fastest growing developing countries with advancing population of elderly. The need for long term care for elderly in Indonesia is already discussed in previous studies (Agustin et al., 2019). Another study indicates that long term care for elderly in Indonesia has been established using community empowerment by conducting integrated health post for the elderly (Pratono \& Maharani, 2018). In addition, the Ministry of Health also highlights the importance of providing adequate long term care for elderly especially for those with high dependency level (Kementerian Kesehatan RI, 2019). However, the sustainability, equitability, and quality of long-term care for elderly in Indonesia remains a challenge (SchröderButterfill, 2020). In line with this, findings of the current study emphasized the need to conduct further research on long term care for elderly in Indonesia as the first level of priority.

It is not surprising that findings of this study indicated family knowledge in caring for elderly also as the first level of priority. It has been argued for decades that family is the 
main caregiver for older people in Indonesia, and family support is essential for caring of the elderly. Family support not only includes emotional, instrumental, and informational, but also a reciprocal relationship between elderly and their family caregiver (Kamaryati \& Malathum, 2020). Therefore, providing support including training for family caregiver is important. Previous studies have identified this issue, for example, the exploration of family experience in caring for elderly with dementia (Ibad et al., 2017) and support for family of self-care ability in community (Suardana et al., 2018). As indicated by findings of this current study, more research is needed on family issues and support for family caregiver in providing adequate care over time to elderly.

A standard competency is important to ensure health care professionals meet expected and required knowledge and skill to provide care. Standard competency in Gerontological Nurse in other countries such as Iran has been discussed in the literature (Purfarzad et al., 2019). Although the need and the roles of nursing in elderly care have been identified in Indonesia for almost two decades, no studies on the development and evaluation of standard competency of Gerontic Nurse are conducted. Findings of our current study support that the development of standard competency of Gerontic Nurse in Indonesia is essential and also becomes the first level priority.

Nutritional status is a person's health condition that may be influenced by the intake and utilization of nutrients. In elderly, nutritional status may involve food intake and body mass index. Nutritional status of elderly is another research area found as the first level of research priority in this study. This supports previous evidence that nutritional status is an important measure for health of elderly as poor nutritional status is considered as a risk factor for frailty (Setiati et al., 2019). Furthermore, malnourished among elderly is also found to be associated with less functional capacity and low independence (Arjuna et al., 2017). However, despite evidence suggesting the relationship between nutritional status and health of elderly, research around this issue is still limited. Some more studies in the Indonesian context focusing on nutritional status are important.

Personal hygiene includes bathing, dressing, toileting, and oral hygiene. Personal hygiene especially in frail older people is another important issue and was identified as another area of the first level of priority in research for Gerontic Nursing. Attending personal hygiene in home setting has been identified as an important role of nursing (Hørdam et al., 2017). Personal hygiene in elderly may influence physical condition. More importantly, it is considered as a symbol of dignity in many societies. A study found that personal hygiene is an indicator for quality of life in globalization era (Hinek et al., 2019).

Psychological problems in elderly including anxiety, depression and loneliness are prevalent both in institutionalized and non-institutionalized elderly (Hassan et al., 2017). More evidence is essential in the Indonesian context especially what is best to handle the psychological problems. This is in line with the finding of this study, as this issue is found as the priority research area level 2.

Similar to psychological problems, research on daily living activities in elderly is also crucial and agreed as the priority research area level 2 in this research. Daily living activities include eating, bathing, dressing, toileting and transferring. As age advancing, together with declining in some functional status of elderly, fulfilment in daily living activities is a challenge especially in frail elderly (Ran et al., 2017).

Quality of life, prevention of fall and increasing immune system in elderly are considered as research area with priority level 3. Quality of life in elderly could be both subjective and objective. Subjective quality life involved with elderly's satisfaction and appreciation with his or her living status. This includes personal income, the degree of feeling safe when elderly travels outside the house, and perceived health status. Meanwhile, objective quality of life involves the observation of living standard including safety of the street and outside living condition and quality of health care (Şahin et al., 2019).

The prevalence of fall among elderly becomes a great concern as it shows alarming number of $29 \%$ (Susilowati et al., 
2020). When 1 among 3 elderly lives in fear of falling, best measure and strategies to prevent fall are imperative. Fall may impact on physical and psychological well-being of elderly. Physical impact may include wound, fracture, and head trauma. Psychological impact include fear of falling and depression. This may also lead to worsen health status, poor quality of life and higher burden of care for family. Therefore, more research on fall prevention in elderly is also essential.

Immune system in elderly is another important issue to be discussed following two reasons. Firstly, influenza vaccine is not included in the national policy as a mandatory immunization (Susilarini et al., 2020). Secondly, it is acknowledged that infectious diseases such as influenza virus infection among elderly is a concern in Indonesia especially in Pandemic Covid-19 (Azwar et al., 2020). Therefore, conducting research on immune system and intervention on how to increase immune system among elderly is important.

Although caregiving for elderly by family members is pivotal in the Indonesian context due to its cultural background, it is inevitable that providing alternative residential aged care facilities for frail or sick elderly is important. This is probably because of globalization and the need to work outside house for other family members especially younger generation, making alternative aged care facilities becomes more apparent. This was highlighted in this study as research priority area level 7 .

It is evident that with the increase number of elderly populations, especially those with chronic diseases and multimorbidity conditions, theuse ofmedicationalso increases (Lavan et al., 2016). Multimorbidity then leads to polypharmacy (Abdulah et al., 2018). If polypharmacy is not managed well, it may cause medication error, which may further develop new comorbidity or complication or worsen patient existing condition. Therefore, it is essential to find evidence on medication management, on how elderly cope with medications and polypharmacy, as well as evidence on how to reduce medication error among elderly patients.

In this globalization era, research on technology support in caring for elderly is also a priority. It is evident in this study that this issue is agreed by participant as the priority area level 8. Technology support includes not only support for direct care for elderly such as technology for fall detection or equipment for fulfilment of daily living activities, but also support for better care coordination among nurses and interdisciplinary team such as supplementation with information technology for communication and care coordination (Blumenthal et al., 2016).

Interestingly, although neglect and aloneness among elderly in Indonesia are identified by previous studies (Sahar et al., 2018), they were considered as the lowest research priority by participants. This may be due to the fact that the concept of neglect and aloneness are poorly understood in Indonesia.

\section{Conclusion}

One of distinguished advantages from this study related to the use of Delphi study is that the findings of this study have the depth of quality data resulted from round 1 . The data from round 1 is validated and agreed by adequate sample size in round 2 . Two rounds Delphi study in this research result in thirty-six research areas that are classified into ten levels of research priority in Gerontic Nursing. Among the 36 research areas, 5 of them are considered as level 1 priority. These include long term care for elderly, family knowledge on caring for elderly, personal hygiene in elderly, standard competency of Gerontic Nurse, and nutrition in elderly. All these areas are the essentials roles of nursing and they give significant implications for nursing.

There are three implications for nursing practice and nursing research arising from this study. First, nurse researchers/ nurse academics in Gerontic Nursing may refocus their research to fit with the research priorities resulted from this study. Second, nurse practitioners in various settings should work together in collaboration with nurse researchers/nurse academics as a research team to conduct rigorous research. Third, nurse practitioners should apply findings from research in their practice to support quality elderly care in Indonesia. 
I Gede Putu Darma Suyasa: Research Priority of Gerontic Nursing in Indonesia: Findings from a Delphi Study

However, this study has some limitations. Firstly, although the sample size in this study is considered adequate, the number of nurses with expertise in Gerontic Nursing involved in this study could have been greater. Secondly, it consists of 2 rounds Delphi study. There are several research areas arise from round 2 that have not been examined quantitatively to reach consensus. Future researchers are suggested to re-examined this issue periodically as the health of the elderly is influenced by bio-social-spiritual aspects of individual, family, community, and environment. Similarly, health care for the elderly is also dynamic, influenced by socioculture and policy changes.

\section{Acknowledgment}

We would like to express our gratitude to Institute of Technology and Health Bali for the funding support of this study. Thank you also to members of Gerontic Nursing Association of Indonesia (Ikatan Perawat Gerontik Indonesia/ IPEGERI) for supporting this study.

\section{References}

Abdulah, R., Insani, W. N., Destiani, D. P., Rohmaniasari, N., Mohenathas, N. D., \& Barliana, M. I. (2018). Polypharmacy leads to increased prevalence of potentially inappropriate medication in the Indonesian geriatric population visiting primary care facilities. Therapeutics and Clinical Risk Management, 14, 1591-1597. https://dx.doi. org/10.2147\%2FTCRM.S170475

Acosta, A. da S., Barbosa, S. de F. F., \& Dal Sasso, G. T. M. (2020). Nursing research priorities in critical care in Brazil: Delphi Study. Revista LatinoAmericana de Enfermagem, 28. https://doi. org/10.1590/1518-8345.4055.3370

Agustin, D., Nugraha, S., Suratmi, T., Susanti, F., Wimardhani, Y., \& Rahardjo, T. B. W. (2019). Basic Long-Term Care Training for Informal Caregivers by the EPA Returnees and Local Trainers in Depok City, West Java, Indonesia. Journal of International Dental and Medical Research, 12(4), 1676-1680.
Arjuna, T., Soenen, S., Hasnawati, R. A., Lange, K., Chapman, I., \& Luscombe-Marsh, N. D. (2017). A cross-sectional study of nutrient intake and health status among older adults in Yogyakarta Indonesia. Nutrients, 9(11), 1240. https://doi.org/10.3390/ nu9111240

Azwar, M. K., Setiati, S., Rizka, A., Fitriana, I., Saldi, S. R. F., \& Safitri, E. D. (2020). Clinical Profile of Elderly Patients with COVID-19 hospitalised in Indonesia's National General Hospital. Acta Medica Indonesiana, 52(3), 199.

Biro Pusat Statistik. (2019). Statistik penduduk lanjut usia 2019 (2019's Elderly population statistics). Biro Pusat Statistik. Retrieved March 24, 2020, from https:// www.bps.go.id/publication/2019/12/20/ ab17e 75 dbe 630 e05110ae 53 b/statistikpenduduk-lanjut-usia-2019.html

Blumenthal, D., Chernof, B., Fulmer, T., Lumpkin, J., \& Selberg, J. (2016). Caring for high-need, high-cost patients - an urgent priority. N Engl j Med, 375(10), 909-911. https://doi.org/10.1056/nejmp1608511

Collins, S., Yen, P.-Y., Phillips, A., \& Kennedy, M. K. (2017). Nursing informatics competency assessment for the nurse leader: The Delphi study. JONA: The Journal of Nursing Administration, 47(4), 212-218. https://doi.org/10.1097/ nna.0000000000000467

Cooper, E., Spilsbury, K., McCaughan, D., Thompson, C., Butterworth, T., \& Hanratty, B. (2017). Priorities for the professional development of registered nurses in nursing homes: a Delphi study. Age and Ageing, 46(1), 39-45. https://doi.org/10.1093/ageing/ afw 160

Diamond, I. R., Grant, R. C., Feldman, B. M., Pencharz, P. B., Ling, S. C., Moore, A. M., \& Wales, P. W. (2014). Defining consensus: a systematic review recommends methodologic criteria for reporting of Delphi studies. Journal of Clinical Epidemiology, 67(4), 401-409. https://doi.org/10.1016/j. 
I Gede Putu Darma Suyasa: Research Priority of Gerontic Nursing in Indonesia: Findings from a Delphi Study

jclinepi.2013.12.002

Fitriana, L. A., Ufamy, N., Anggadiredja, K., Amalia, L., Setiawan, S., \& Adnyana, I. K. (2020). Demographic Factors and Disease History Associated with Dementia among Elderly in Nursing Homes. Jurnal Keperawatan Padjadjaran, 8(2), 130-138. https://doi.org/10.24198/jkp

Grove, S. K., \& Gray, J. R. (2018). Understanding nursing research: building an evidence-based practice. Elsevier Health Sciences.

Hassan, W., Abd El-Halim, Z., Ahmed, S., \& Mostafa, N. (2017). Psychological problems as perceived by institutionalized and non-Institutionalized elderly. Journal of Education and Practice, 8(33), 61-67.

Hinek, S., Stanić, I., \& Škarica, J. (2019). Importance of promoting quality of life of elderly people under the influence of globalization. Ekonomski Vjesnik, 32(1), 9-21.

Hørdam, B., Brandsen, R. V., Frandsen, T. K., Bing, A., Stuhaug, H. N., \& Petersen, K. (2017). Nurse-assisted personal hygiene to older adults $65+$ in home care setting. Journal of Nursing Education and Practice, 8(2), 23. http://dx.doi.org/10.5430/jnep.v8n2p23

Ibad, M. R., Ahsan, A., \& Lestari, R. (2017). Caring Experience of Primary Family Caregiver in Elderly with Dementia at Indonesian Rural Area. Health Science International Conference (HSIC 2017), 316-323. https://dx.doi.org/10.2991/hsic17.2017 .49

Kamaryati, N. P., \& Malathum, P. (2020). Family Support: A Concept Analysis. Pacific Rim International Journal of Nursing Research, 24(3), 403-411.

Keeney, S., Hasson, F., \& McKenna, H. (2017). The Delphi technique in nursing and health research. Wiley Blackwell.

Kementerian Kesehatan RI. (2019). Policy paper: analisis kebijakan mewujudkan lanjut usia sehat menuju lanjut usia aktif (active ageing) (Policy paper: policy analysis to realize healthy elderly towards active elderly (active ageing). Kementerian Kesehatan RI. Retrieved July 24, 2020, from http:// www.padk.kemkes.go.id/uploads/download/ Analisis_Lansia.pdf

Lavan, A. H., Gallagher, P. F., \& O’Mahony, D. (2016). Methods to reduce prescribing errors in elderly patients with multimorbidity. Clinical Interventions in Aging, 11, 857. https://doi.org/10.2147/cia.s80280

Lukman, M., Sihombing, F., \& Meilianingsih, L. (2018). Factors Associated with Death Anxiety in Elderly Batak Tribe who Live in Bandung. Jurnal Keperawatan Padjadjaran, 6(2), 139-145. https://doi.org/10.24198/jkp.

Maryam, R. S., Resnayati, Y., Riasmini, N. M., \& Sari, C. W. M. (2018). Effect of family support intervention towards quality of life with Elderly's hypertension in community. Jurnal Keperawatan Padjadjaran, 6(3), 281-288. https://doi.org/. 10.24198/jkp.

Meiner, S., \& Yeager, J. (2019). Gerontologic nursing. Elsevier Health Sciences.

Pratono, A. H., \& Maharani, A. (2018). Longterm care in Indonesia: The role of integrated service post for elderly. Journal of Aging and Health, 30(10), 1556-1573. https://doi. org/10.1177/0898264318794732

Purfarzad, Z., Bahrami, M., Keshvari, M., Rafiei, M., Sivertsen, N., \& Cert, G. (2019). Effective factors for development of gerontological nursing competency: A qualitative study. The Journal of Continuing Education in Nursing, 50(3), 127-133. https:// doi.org/10.3928/00220124-20190218-08

Ramelet, A. S., Gill, F., \& Group, I. (2012). A Delphi study on National PICU nursing research priorities in Australia and New Zealand. Australian Critical Care, 25(1), 41-57. https://doi.org/10.1016/j. aucc.2011.08.003

Ran, L., Jiang, X., Li, B., Kong, H., Du, M., Wang, X., Yu, H., \& Liu, Q. (2017). 
I Gede Putu Darma Suyasa: Research Priority of Gerontic Nursing in Indonesia: Findings from a Delphi Study

Association among activities of daily living, instrumental activities of daily living and health-related quality of life in elderly $\mathrm{Yi}$ ethnic minority. BMC Geriatrics, 17(1), 1-7. https://doi.org/10.1186/s12877-017-0455-y

Sahar, J., Riasmini, N. M., \& Nurviyandari, D. (2018). Reducing neglect and improving social support for older people following a self-help group in the poor urban community of Jakarta, Indonesia. Enfermeria Clinica, 28, 66-69. https://doi.org/10.1016/S11308621(18)30039-1

Şahin, D. S., Özer, Ö., \& Yanardă̆, M. Z. (2019). Perceived social support, quality of life and satisfaction with life in elderly people. Educational Gerontology, 45(1), 6977. https://doi.org/10.1080/03601277.2019.1 585065

Schröder-Butterfill, E. (2020). Long-term care for older people in Indonesia: Unsustainable and unjust? The Inaugural Symposium of the Special Interest Group (SIG) on Ageing in Africa, Asia and Latin America. Retrieved July 28, 2020, from http://eprints.soton. ac.uk/id/eprint/442027

Setiati, S., Laksmi, P. W., Aryana, I. G. P. S., Sunarti, S., Widajanti, N., Dwipa, L., Seto, E., Istanti, R., Ardian, L. J., \& Chotimah, S. C. (2019). Frailty state among Indonesian elderly: prevalence, associated factors, and frailty state transition. BMC Geriatrics, 19(1), 1-10. https://doi.org/10.1186/s12877019-1198-8

Suardana, W., Yusuf, A., \& Purnomo, W. (2018). Self-help group therapy: The enhancement of self-care ability and quality of life among the elderly in Bali, Indonesia. Indian Journal of Public Health Research \& Development, 9(11), 76-80. http://dx.doi. org/10.5958/0976-5506.2018.01698.4

Susilarini, N. K., Haryanto, E., Ikawati, H. D., Puspa, K. D., Noviyanti, W., \& Pawestri, H. A. (2020, January). Hospitalized Influenza Elderly Patients in Indonesia, 2013-2018. 19th International Congress on Infectious Diseases.

Susilowati, I. H., Nugraha, S., Sabarinah, S., Peltzer, K., Pengpid, S., \& Hasiholan, B. P. (2020). Prevalence and risk factors associated with falls among communitydwelling and institutionalized older adults in Indonesia. Malaysian Family Physician: The Official Journal of the Academy of Family Physicians of Malaysia, 15(1), 30. https:// doi.org/10.1155/2018/5964305

Suyasa, I. G. P. D. (2013). Development of a Self-care Guideline of Faecal Incontinence for Community-dwelling Older People in Indonesia. Flinders University of South Australia, School of Nursing and Midwifery. United Nations. (2020). World population ageing 2020. United Nations. 